持続的筋力発揮時の運動単位筋振動信号と運動単位の同期化活動

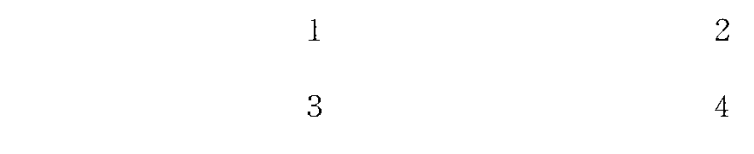

\title{
MOTOR UNIT MECHANOMYOGRAPHIC SIGNAL AND SYNCHRONIZED ACTIVITY IN MOTOR UNITS DURING VOLUNTARY MUSCLE CONTRACTIONS
}

\author{
SHigeru Morimoto, Chigusa ISHiWata, \\ NAOMI MiYAmOTO and Mifuyu Kamo
}

\begin{abstract}
The aim of the present study was to investigate, by analysis of motor unit action potential (MUAP) and motor unit mechanomyogram (MUMS) wave-forms, whether the synchronized activity of motor units (MUs) is a factor in increasing the integrated value of a mechanomyogram dur. ing muscle contraction at relatively low tension levels. MUAP and MUMS of m. vastus medialis were recorded by $\mathrm{Ag} / \mathrm{AgCl}$ disc electrode $(5 \mathrm{~mm} \phi)$ and condenser microphone $(10 \mathrm{~mm} \phi)$, respectively, during muscle contractions, brief isometric constant contractions (BICC) and prolonged isometric constant contraction (PICC) at the target torques from just above the decruitment threshold torque of the objective MU to $20 \%$ of maximal voluntary contraction (MVC). The degree of synchronization of MUs, defined from the amplitude of late positive deflection $\left(V_{\mathrm{LPD}}\right)$, could be seen in MUAP wave-forms.

The amplitude of the positive phase in MUMS (MS $-V_{\text {positive }}$ ) had no relationship with the increase of $\mathrm{V}_{\mathrm{LPD}}$ in BICC condition. During PICC, MS $-\mathrm{V}_{\text {positive }}$ and $\mathrm{V}_{\mathrm{LPD}}$ increased with time. Applying linear regression analysis on the relation between $V_{L P D}$ and $M S-V_{\text {positive, except for data at }}$ $20 \% \mathrm{MVC}$, there was significant correlation. However, the scale of the time increments, between $\mathrm{V}_{\mathrm{LPD}}$ and MS $-\mathrm{V}_{\text {positive, }}$ were different comparing exponential and logarithmic figures, respectively. Therefore, in the present experiment, the meaningful relationship between the two parameters could not be introduced. It is necessary to further investigate the relationship between the two parameters including the firing frequency of MU, intramuscular pressure and extent of recording area of both sensors.
\end{abstract}

(Jpn. J. Phys. Fitness Sports Med. 2009, $58: 365 \sim 378$ )

key word : motor unit, MUAP, MMG, synchronized activity, prolonged activity.

$$
\text { I. 序論 }
$$

収縮する骨格筋が特徵的な低周波数の“音”を発 生することは古くから知られている．この“筋音” 信号は, 骨格筋 (線維) の収縮状態を反映する可能 性が示唆されている (Barry et al. 1985 '), Orizio et al. $1989^{2)}$, Kimura et al. $2004^{3)}$, Rhatigan et al.

${ }^{1)}$ 横浜国立大学教育人間科学部保健体育

干240-8501 神奈川県横浜市保土ヶ谷区常盤台79-2

2) 横浜国立大学教育人間科学部 干240-8501 神奈川県横浜市保土ヶ谷区常盤台79-2

3) 横浜国立大学教育学研究科健康・スポーツ系教育専修 厂240-8501 神奈川県横浜市保土ヶ谷区常盤台79-2

${ }^{4)}$ 日本女子体育大学体育学部

₹157-8565 東京都世田谷区北烏山8-19-1
$1986^{4)}$, Hufschmidt et al. $1987^{5)}$, Yoshitake \& Moritani $1999^{6)}$ ) ．“筋音” は, 筋電図法から推定 される情報（MUの活動参加樣式：Akataki et al. $2001)^{7)}$ とともに筋電図法では抽出困難な筋線維収 縮系実質の情報を同時に提供する可能性がある.生 体内における骨格筋の収縮状態を非侵襲的に推定す ることとなり，医療・リハビリテーション・体力科

Faculty of Education and Human sciences, Yokohama National University.

Faculty of Education and Human sciences, Yokohama National University.

Master Course of Health and Sports Education, Yokohama National University.

Faculty of Exercise Physiology, Japan Women's College of Physical Education. 
学など広い分野への貢献性が期待できる.したがって， “筋音” 信号の発現機構の解明と共に, 筋音を応用し た実験結果の解釈方法の開発に必要性が存在する.現 在 “筋音” 信号は“ mechanomyogram: MMG” の名 称の使用力提唱されている8).

持続的一定筋力発揮時の MMG 及び兴の積分值 （iMMG）は発揮する筋力に依存して種々の変化動態 を示す. 発揮筋力を $20 \%$ 随意的最大筋力 (maximal voluntary contraction: MVC) 以下に設定したとき， $i M M G$ は増加傾向を示す ${ }^{2,9,10)}$. この増加は, 休止 していた運動単位 (motor unit: MU) の活動参加， 活動するMUの発火頻度の変化, MU間の同期化活 動などに起因すると考えられている．

MUの MMGの振幅はMU 発火頻度に反比例する と報告されている ${ }^{11)}$. また , ランプ状筋力発揮を 行ったときの上腕二頭筋 $M M G$ と筋力の関係につい て, 発揮筋力 $60 \%$ MVC 程度までRMS-MMG は発揮 筋力に対して比例的に増大し，60\% MVC以上で咸 少に転じることを観察している．増加はMUの活動 参加, 減少は活動参加している MU の放電頻度の増 加によると考察されている7) . 被験筋全体のMMG 現象を, 不完全強縮から完全強縮への变化といった 筋線維 (群) 収縮状態から解釈可能であることを示 唆する結果と位置づけられる．

低い目標筋力で持続的一定筋力発揮時の表面筋電 位波形 (myoelecric signal:MES) に注目したとき， その振幅, 積分值 (iMES) は時間に伴った増加傾 向にある.MES, iMESの増加は新しいMUの活動 参加および活動する MUの放電間隔の短縮（放電頻 度の増加）に起因し, 活動するMUの筋疲労による 発揮筋力の低下を補償し目標筋力に発揮筋力を一致 させるための調節 (補償) 機構と考えられている . また，筋力発揮に多くのMUの活動参加か関与する ことは, MU間の同期化活動の確率が高くなること を示唆する ${ }^{12)}$. このような $M U$ 活動は MMG に次に 示すような影響を及ぼすものと推定される . (1)観 察対象の MUの MMG (motor unit mechanical signal : MUMS) は発火頻度の上昇により振幅が減少 し, 弚の減少は筋全体の $M M G$, iMMG を減少する 方向に働き，(2) MUの活動参加および同期化活動 は筋全体の MMG 増加に働きかける . (1)と (2)の現 象はMMGに相反的に反映される.しかし, MUの 同期化活動が $M M G$ 増加に働きかけることは記載さ
れているが $8,13,14)$, 随意的筋力発揮時の MU 同期 化活動とMMGの関係を検討した実験結果は未だ示 されていない，本実験では，持続的筋力発揮中に， 観察対象 MU と背景に活動するMU との同期化活動 とMUMSの振幅変化の関係に注目した .

観察する MU と背景活動する MU との同期性の評 価については以下の解析方法を適用した . 運動終板 から筋一腱移行部の中間部分で運動単位活動電位 (motor unit action potential:MUAP) を単極導出 した時，伝導に伴って，初期陽性相，伝導性の陰性 スパイク, 光の後に緩徐な陽性相といった 3 相性を 示す.また第 3 相の電位に電気緊張性の陽性電位が 重畳する (late positive deflection:LPD) ${ }^{15,16)}$. LPD は, MUAPが伝導し筋一腱移行部に到達した 時点に発現すると考えられている ${ }^{15,16)}$. さらに， LPDの振幅は発揮筋力に比例し, 観察対象 MUAP と同期して筋一腱移行部に到達した背景活動の MUAPの相対的な数を表すものと考えられている . すなわち，観察対象のMUAP と背景で活動する MUAP との筋一腱移行部での非特異的な同期性の 指標となりうる .

本報告では, 単一MUのMUAP とMUMS を同時 に導出し，LPDから推定するMU同期化活動と MUMS 振幅の関係を観察し, 同期化活動の $i M M G$ への貢献性について検討することを目的とした .

\section{II. 実 験 方 法}

実験実施に先立ち本実験の目的，意義及び想定さ れる危険性について充分な説明を行い, 参加に同意 の得られたものを被験者として実験参加を依頼し た.この実験は横浜国立大学教育人間科学部倫理委 員会からの承認を得て実施した . 被験者は神経一筋 疾患およひ障害履歴の無いものであった .

MES, MUAP と MMG, MUMS は 7 名の成人男性 被験者 $(24 \sim 56$ 歳, 身長 : $172.7 \pm 2.4 \mathrm{~cm}$; 体重 : $62.3 \pm 1.9 \mathrm{~kg})$ の右内側広筋より導出した . 被験者 には, 実験実施日 2 日前より，高強度の身体活動は 控えるように依頼した . 実験室環境温は $23-26{ }^{\circ} \mathrm{C} の$ 範囲に調節した。

\section{A . 信号の記録}

被験者は実験台（高さ $70 \mathrm{~cm}$ ) に腰かけ, 下腿を 下垂した . 被験者の腰部はベルトを介して実験台に 
固定した . また，実験を通じて，上肢は腕組みの姿 勢とした . 膝関節伸展張力を等尺性に検出するため に実験側足関節部にベルトを固定し，ワイヤーを介 してロードセル (RTB-100K, 日本光電) に接続した . ロードセルの出力はストレインアンプ ( $6 \mathrm{M} 84$, 日 本電気三栄; low-pass filter $100 \mathrm{~Hz}$ ) にて増幅し た . 股関節と膝関節角度は90から95度に規定した。

MMG, MUMS 導出にはコンデンサー型マイクロ フォンを用いた (DMS-011, ダイヤメディカルシス テム, band-pass : $2-1000 \mathrm{~Hz}$, 直径: $10 \mathrm{~mm}$, 重量: 9 g). MUMS 導出マイクロフォンの装着位置は観察対 象 MU の運動終板領域とし, 実験に先立ちMUAP 波 形の解析から位置の特定を行った ${ }^{15 〜 17)}$. マイクロ フォンはドラムの外部との気密性を保つように，リ ング型両面接着テープで皮膚表面上に固定した . マ イクロフォンの出力は直流増幅器 (DPA-251S, ダ イヤメディカルシステム; 入力抵抗: $1 M \Omega$, 出力 抵抗: $100 \Omega$, band-pass: $1-1 \mathrm{kHz}$ ) に入力し, 増幅 した.MMG 導出のマイクロフォンは, MUMS 導出 マイクロフォン装着位置からの筋線維走行に対して 内側または外側直行方向へ $30 \mathrm{~mm}$ 以上離れた位置に 装着した .

筋電位信号導出には 2 対の $\mathrm{Ag} / \mathrm{AgCl}$ 皿型電極を 用いた (直径 $5 \mathrm{~mm})$. 1 対は MUAP 導出電極とし, 1 対の一方の電極はマイクロフォンセンサー直近の 末梢側，筋線維の走行方向に沿った位置に絆創亳(シ ロバン230602, 日廣薬品) にて装着した .また，他 の 1 対はMES 導出電極とし, MMG 導出マイクロフ オンの直近, 末梢側に装着した .これらの電極は差 動増幅器 (DPA-401S, ダイヤメディカル; 入力抵 抗: $50 \mathrm{M} \Omega$, 出力抵抗: $100 \Omega$, band-pass: $3-10$ $\mathrm{kHz}$ ）の陽極入力端子に接続し，他の電極は，膝蓋 骨上の皮膚に装着し, 増幅器の陰極入力端子に接続 した (単極導出法). 電極間距離は約 $90 \mathrm{~mm}$ で, 電 極間抵抗は $20 \mathrm{k} \Omega$ 以下となるように角質除去クリー ム (ケラチンクリーム, フクダ電子) にて皮膚を研 磨後, 酒精綿にて払拭した . 単極導出に比して高い 目標筋力まで比較的安定したMUAP 波形を導出可 能な双極導出法にて MUAP を導出し, 加算平均の トリガーパルスとして用いた (C.データ処理・解 析部参照). 双極電極は MUMS 導出マイクロフォン の中枢側に電極間距離 $10 \mathrm{~mm}$ をもって装着した .

全ての信号は PCM データレコーダー (PC-108M ,
ソニーマグネスケール，周波数帯域: $\mathrm{DC}-5 \mathrm{kHz}, 入$ 力抵抗: $100 \mathrm{k} \Omega$,) に入力し, DAT テープに保存し た。

\section{B. 実験手順}

被験者には，実験装置・手法，環境に慣れること， また表面電極によるMU活動電位導出位置の特定， を目的とした実験準備期間を設定した .

実験に先立ち，被験者の等尺性膝関節伸展での MVCを測定した．MVCは，規定した実験姿勢にて 3 回の測定試技での筋力の平均值とした . MVC 測 定後, 電極, マイクロフォンの装着を行い, 30分以 上の時間間隔を取りデータ収集を行った . 課題実 験に入る前に，観察対象のMUの活動参加閾値を， 筋力発揮勾配 $10 \mathrm{~N} \cdot \mathrm{s}^{-1}$ にて求めた. 15秒間隔で10 回実施し，关の平均值を MUの活動参加閾值とした .

実験は以下に記す 2 種類の課題から構成した . 課題 1 : 被験者は約 $10 \mathrm{~N} \cdot \mathrm{s}^{-1}$ の筋力発揮勾配にて目 標筋力まで筋力発揮を行い, 弚の後目標筋力を 11 秒 間一定保持した (brief isometric constant contraction : BICC) . 目標筋力は MU の活動参加閾值張力 , 活動参加閾值張力上から $20 \% \mathrm{MVC}$ 間の任意の 4 種 の筋力およびMUが極低頻度にて活動する時点の結 果を得るために活動休止筋力 (decruitment threshold) 直上，計 6 種類に設定した．各目標筋 力発揮を，2 分の間隔を持って，5回試行した . 課題 2 : 課題 1 の終了後15分以上の時間を挿入し, 課題 2 を実施した.

被験者は約 $10 \mathrm{~N} \cdot \mathrm{s}^{-1}$ の筋力発揮勾配にて目標筋力 まで筋力発揮を行い，弚の後目標筋力を一定保持し た (prolonged isometric constant contraction: PICC) . PICCの中止時点は, 目標筋力に発揮筋力を 一致させる調節が出来なくなった時点，または筋力 振戦が明らかに出現した時点のいずれかとした . こ の時点は任意の験者の視覚的な判断によった . 目標 筋力の設定は, 観察する運動単位の活動参加閾値直 上と $10 ， 20 \% \mathrm{MVC} と し た ．$ 各目標筋力での試行は 実験日を変え，目標筋力を順不同で設定して行った． 電極，マイクロフォンの装着位置は油性インクにて 皮膚上にマークし,同位置に装着することに努めた .

観察対象のMUAP , 目標筋力と発揮筋力は被験 者の目前（約 $1 \mathrm{~m}$ ) に設置したオシロスコープに表 示し, 被験者への視覚的フィードバックおよび験者 
への信号モニターとした .

\section{C. データ処理・解析}

DAT テープに保存された信号はA/D変換器 $[ \pm$ $2.5 \mathrm{~V}$ 入範囲・16-bit 分解能; $\mathrm{AD}-12-16 \mathrm{U}(\mathrm{PCI})$, コンテック］を介してデスクトップコンピュータ に入力し , ソフトウェアー (BIMUTAS-II , キッセ イコムテック) を用いてデータ解析を行った .

BICCでは, 発揮筋力が目標筋力に到達した時点 より1秒後から11秒までの10秒間の信号を解析に供 した.PICCでは, 発揮筋力が目標筋力に到達した 時点より 1 秒後から 11 秒までの10秒間のデータを時 間 0 秒のデータとし, 弚の後 30 秒毎 10 秒間の信号を 解析データとした。
解析を行う前に, MES と MUAPは $3-3 \mathrm{kHz}$ お よびMMGと MUMS は $3-500 \mathrm{~Hz}$ のバンドパスフィ ルター, 筋力信号は $50 \mathrm{~Hz}$ のローパスフィルターで デジタルフィルター処理を行った .

iMES, iMMGは, MES,MMG を全波整流した後， 区間 $100 \mathrm{~ms}$ で10秒間の解析区域から求めた。双極 導出した運動単位活動電位をトリガーパルスとして 用い，単極導出 MUAP および MUMS 原信号を加算 平均し, MUAP, MUMS 波形を10秒解析区域ごと に算出した 、算出されたMUAPからLPDの振幅 $\left(\mathrm{V}_{\mathrm{LPD}}\right), \mathrm{MUMS}$ から陽性相の振幅 (MS- $\left.\mathrm{V}_{\text {positive }}\right)$ を求めた。 $V_{\mathrm{LPD}}$ は, figure 1 に示すように, MUAP 第 3 相陽性電位の減衰軌跡に沿って内挿し，内挿線 から LPD ピークまでの電位とした ${ }^{15)}$.

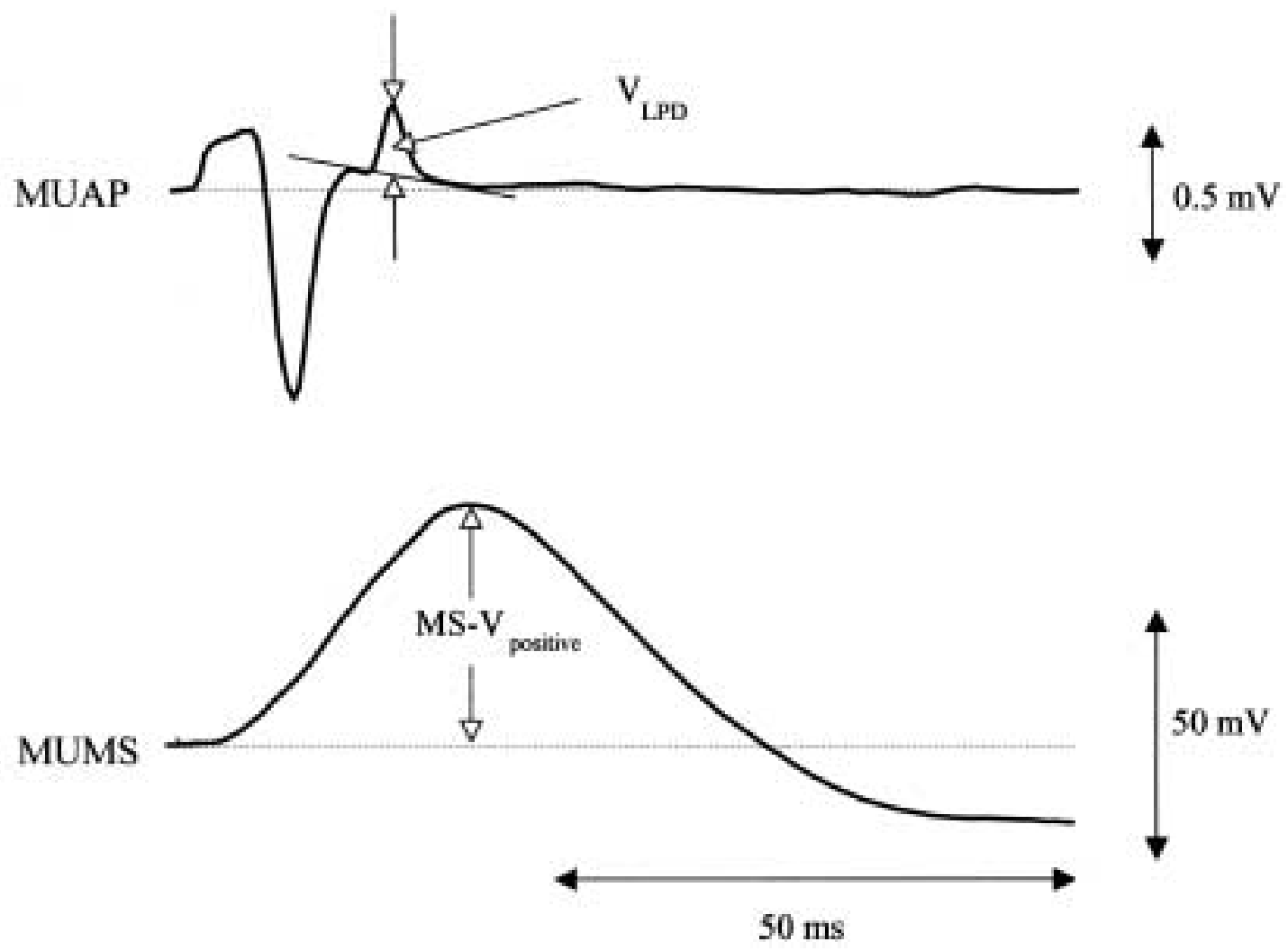

Figure 1. Typical wave form of average MUAP (upper trace) and motor unit mechnomyographical signal (MUMS; lower trace) recorded from $m$. vastus medialis.

MUAP was recorded from the monopolar electrode put on the vicinity of the microphone sensor, distally. MUMS was recorded from a condenser microphone put on the end-plate region of the motor unit. Each wave-form was calculated from the signals of a $10 \mathrm{~s}$-period using the method of spike triggered averaging by reference MUAP signals recorded from the bipolar electrode fastened at the proximal side of the microphone at the end-plate. The amplitude of late positive deflection (LPD) on the third graded positive phase of MUAP $\left(V_{\mathrm{LPD}}\right)$ and the amplitude from base-line to positive peak of MUMS (MS $-\mathrm{V}_{\text {positivc }}$ ) were measured. For the measurement of $\mathrm{V}_{\mathrm{LPI}}$, the amplitude was defined as the voltage between the positive peak and the line intrapolating the third gradual phase of MUAP. 


\section{D. 統計処理}

結果は平均値および標準偏差で現した . PICC 時 の時間に伴う iMES, iMMG，およびMUAP， MUMS の波形パラメーター間は一元配置分散分析で 検定を行った データ間で有意性が認められた場合， 時間 0 秒時データとの比較において Dunnettの多重 比較を行った . 有意差は $5 \%$ 以下の危険率を持って 判定した。

$$
\text { III. 結果 }
$$

被験者のMVC は400 N から650 N(544.3 N \pm 88.6$)$ の範囲にあった .また , 本実験にて観察対象とした MUの活動参加閾値は $0.1-6 \% \mathrm{MVC}$ の範囲にあっ た.

\section{A. BICC 条件下における発揮筋力, IMESと $\mathrm{V}_{\mathrm{LPD}}$ の関係}

観察対象 MUの活動参加閾值から $20 \%$ MVC まで のBICC 条件下における $\mathrm{iMMG}$ と $\mathrm{iMES}$ の変化動態
に関して典型 2 例をfigure 2 に示した .いずれの被 験者においてもiMMG(A), iMES(B)は発揮筋力に 対して直線的な関係にあった .

Figure 2 の実験時に同時導出したMUAPにおけ る $V_{L P D}$ と発揮筋力，及び目標筋力発揮時における iMES との関係を figures 3 A \& B に光れ示した . 実験条件で設定した目標筋力の範囲で， $V_{\mathrm{LPD}}$ は発 揮筋力, MMES に依存し直線的に増大する傾向にあっ た。

図中に示した 2 種類の MUからの双極導出 MUAP は，100N (約 $20 \% \mathrm{MVC}$ ) まで背景活動のMUAPに 比し充分大きな振幅を呈し, 波形も明確に弁別可能 であり，加算平均のトリガーパルスとして用いるこ とができた . 目標筋力 $20 \%$ MVC までのBICCおよ びPICCの全ての試行で解析可能であった MUは 3 被験者，4MUであった .
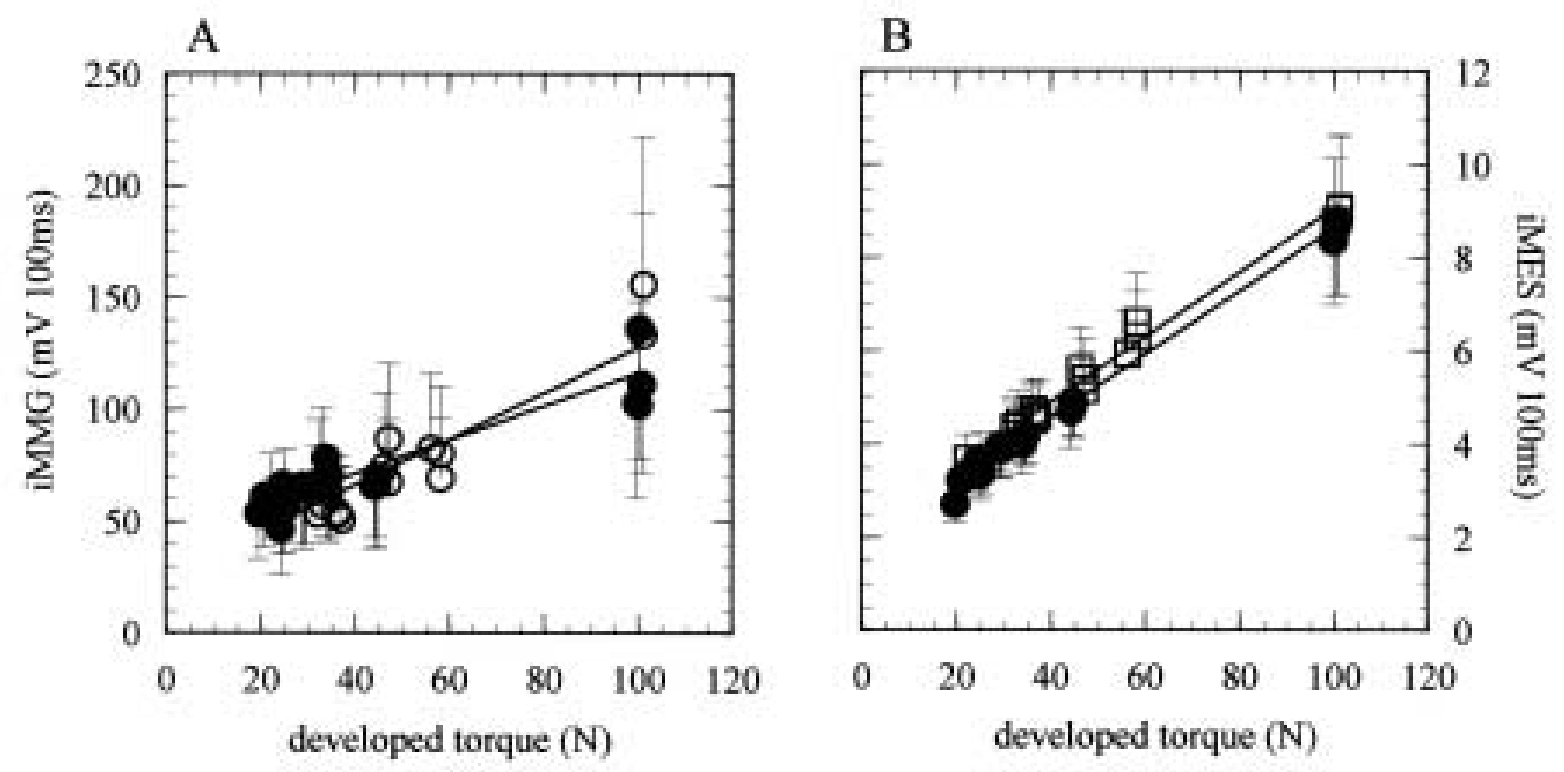

Figure 2. The relationship between developed torque and iMES (A), and $\mathrm{MMMG}(\mathrm{B})$ under a brief isometric constant contraction (BICC) condition at various target torques in two subjects plotted by opened circle and closed circle, respectively. Symbol and attached bar are mean value and standard deviation.

Applied linear regression analysis between the two parameters shows there was significant linear correlation between the regression lines as seen in figures $2 \mathrm{~A}$ and $\mathrm{B}$.

In iMMG:

opened circle $\mathrm{y}=1.02 \mathrm{x}+2.48, \mathrm{r}=0.9125$,

closed circle $y=0.75 x+14.02, r=0.9281$.

In iMES:

opened square $\mathrm{y}=0.07 \mathrm{x}+2.11, \mathrm{r}=0.9940$,

closed square $\mathrm{y}=0.07 \mathrm{x}+1.85, \mathrm{r}=0.9963$. 

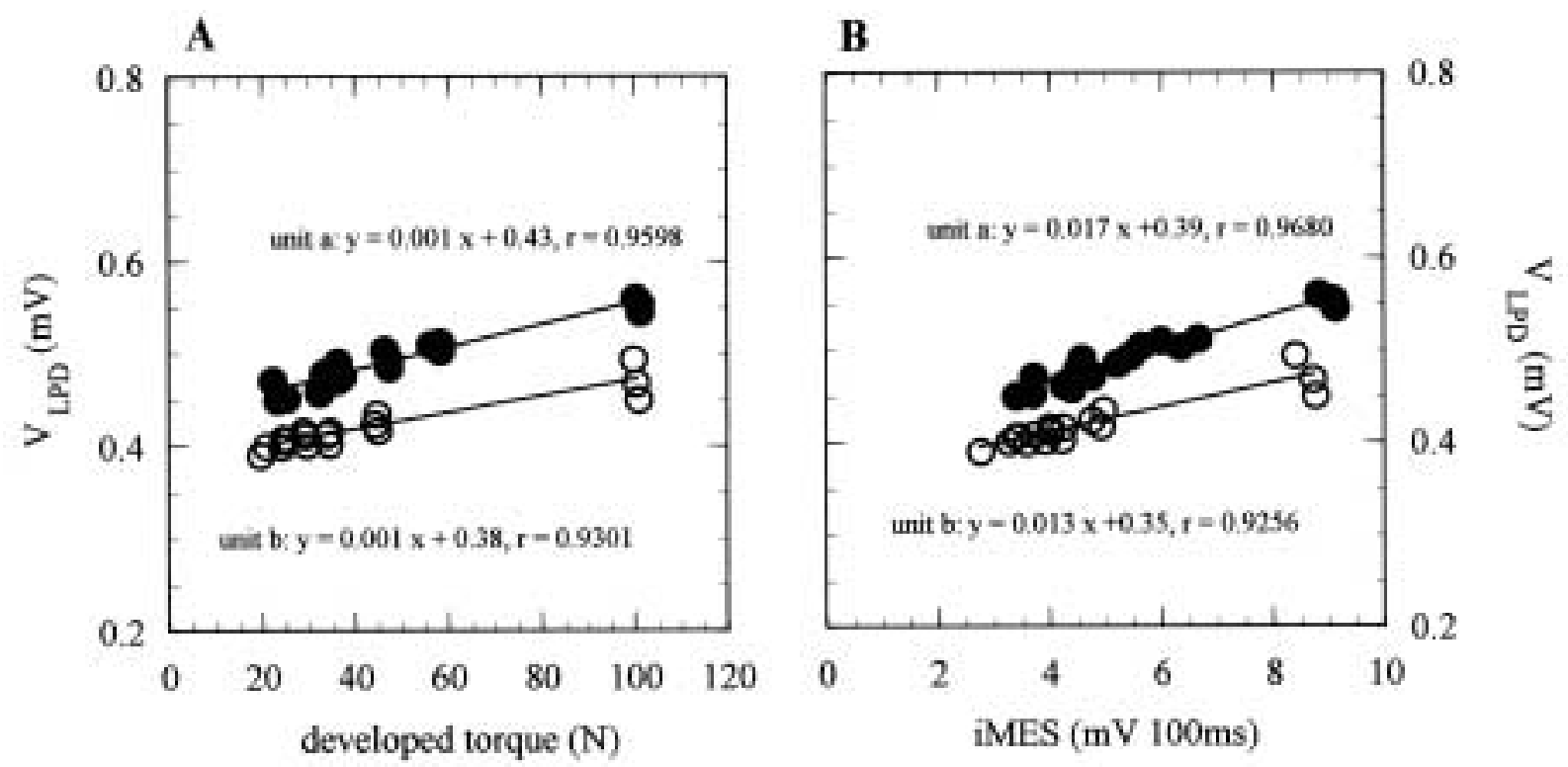

Figure 3. The relationship between $\mathrm{V}_{\mathrm{LPD}}$ and developed torque (A), and iMES (B) under BICC at various target torques. The representative two motor units, from different subjects, are shown with different symbols. For these two motor units, the wave-form of MUAPs was clearly identified for $100 \mathrm{~N}$ (approximately 20\%MVC).

Linear regression analysis showed a significant relationship for every pair.

\section{B. BICC 条件下における $V_{\mathrm{LPD}}$ と $M S-V_{\text {positive }}$ の関係}

Figure 3 に示したMUについて，BICC 条件下に おける $\mathrm{V}_{\mathrm{LPD}}$ と MS-Vpositive の関係を figure 4 に示 した . 両変数間の関係を求めるために便宜的に直線 回帰したところ, unit a に有意な負の相関関係が得 られ, unit aのMS- $\mathrm{V}_{\text {positive }}$ は $\mathrm{V}_{\mathrm{LPD}}$ の増大に伴っ た減少傾向が見られた。しかし, unit a を用いた複 数回の実験において，有意性を示した結果は得られ ず，再現性はなかった．また，他のMUにおいて， $V_{\text {LPD }}$ と MS- $V_{\text {positive }}$ の間に有意な関係は得られな かった . BICC 条件下における MS- $V_{\text {positive }}$ は $V_{\text {LPD }}$ から推定した MUの同期性に対して影響されない結 果であった .

\section{PICC 条件下における iMES, iMMGの変化 動態}

PICCの目標筋力を $30 \mathrm{~N} ， 50 \mathrm{~N}$ おび $100 \mathrm{~N}$ に設定 したときの $i M M G, i M E S の$ 筋力発揮持続時間に伴 う変化動態に関して，1 名の被験者からの代表例 を figures 5 A \& B に示した.iMMG, iMES 初期值 (横 軸 0 秒値) に目標筋力に依存した差異が見られた . 全ての目標筋力でiMMGに増加傾向が見られ，目

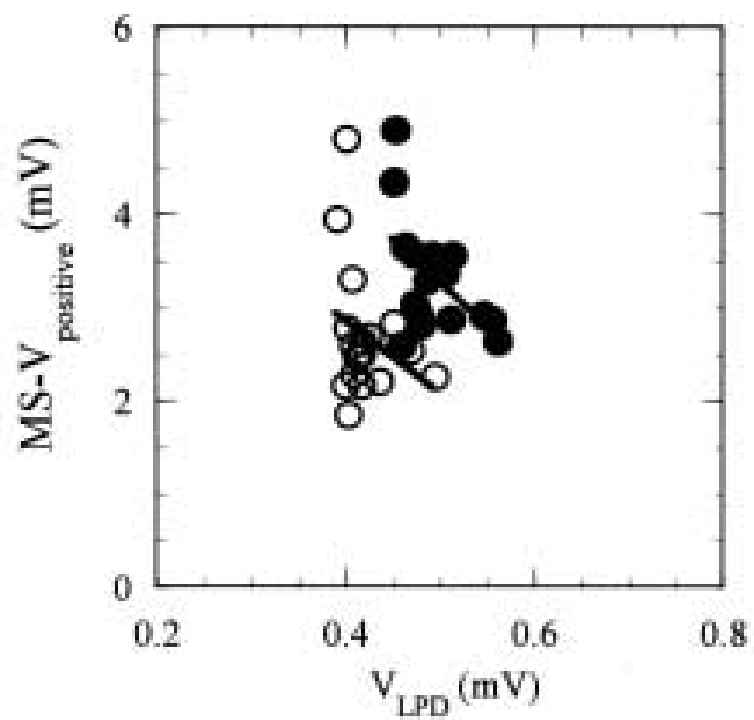

Figure 4. The relationship between $V_{\text {LPD }}$ and $M S-V_{\text {positive }}$ under BICC for the two motor units is seen in figure 4 . The present motor units were the same motor units represented in figures $2 \mathrm{~A}$ and $\mathrm{B}$. Linear regression analysis showed a significant negative correlation for unit a (closed circle) but was not significant for unit b (opened circle).

Unit a (closed circle):

$$
\mathrm{y}=-9.21 \mathrm{x}+7.87, \mathrm{r}=-0.5222,
$$

Unit b (opened circle):

$$
y=-7.71 x+5.94, r=-0.2915 .
$$

Unit a shown in this figure was the only case among the results to show significant correlation. 
標筋力 $30 \mathrm{~N}$ では PICC 初期にほぼ一定値を取り300秒 時で有意な増加となった．50Nでは90秒，100Nで は60秒でiMMGの有意な増加となった . iMMGは， 高い目標筋力でより早期に有意な増加を取る傾向に あった . iMESでは100N 時に他の目標筋力に比較し もつとも遅い時間で有意な増加を示し, $\mathrm{iMMG}$ 変化 動態と異なる傾向にあった．また，7名の被験者に 共通してiMMG, iMESの増加傾向があった . 全被 験者から求めた iMMG およびiMES の初期值に対す る相対值平均值の変化動態を figures 5 C \& D に光れ ぞれ示した．図中シンボル○（C)，○（D) は，観
察対象の MU 活動参加閾値 $(0.1-6 \% \mathrm{MVC})$ で得ら れた結果の平均値としたが, $\mathrm{iMMG}$ 相対値の変化動 態は実数値の目標筋力に依存した変化動態 (figure $5 \mathrm{~A}$ ）と同傾向にあった . また，各々の目標筋力で， iMMG は iMES に比して大きな増加率で推移した .

D. PICC 条件下における $V_{L P D}$ と $M S-V_{\text {positive }}$ の関係

Figures 5 A \& B に示したMMG, MES と同時に記録 した MUAP とMUMSから計測した $V_{\text {LPD }}$ とMS- $V_{\text {positive }}$ の結果をfigures 6 A \& B に光れぞれに示した .
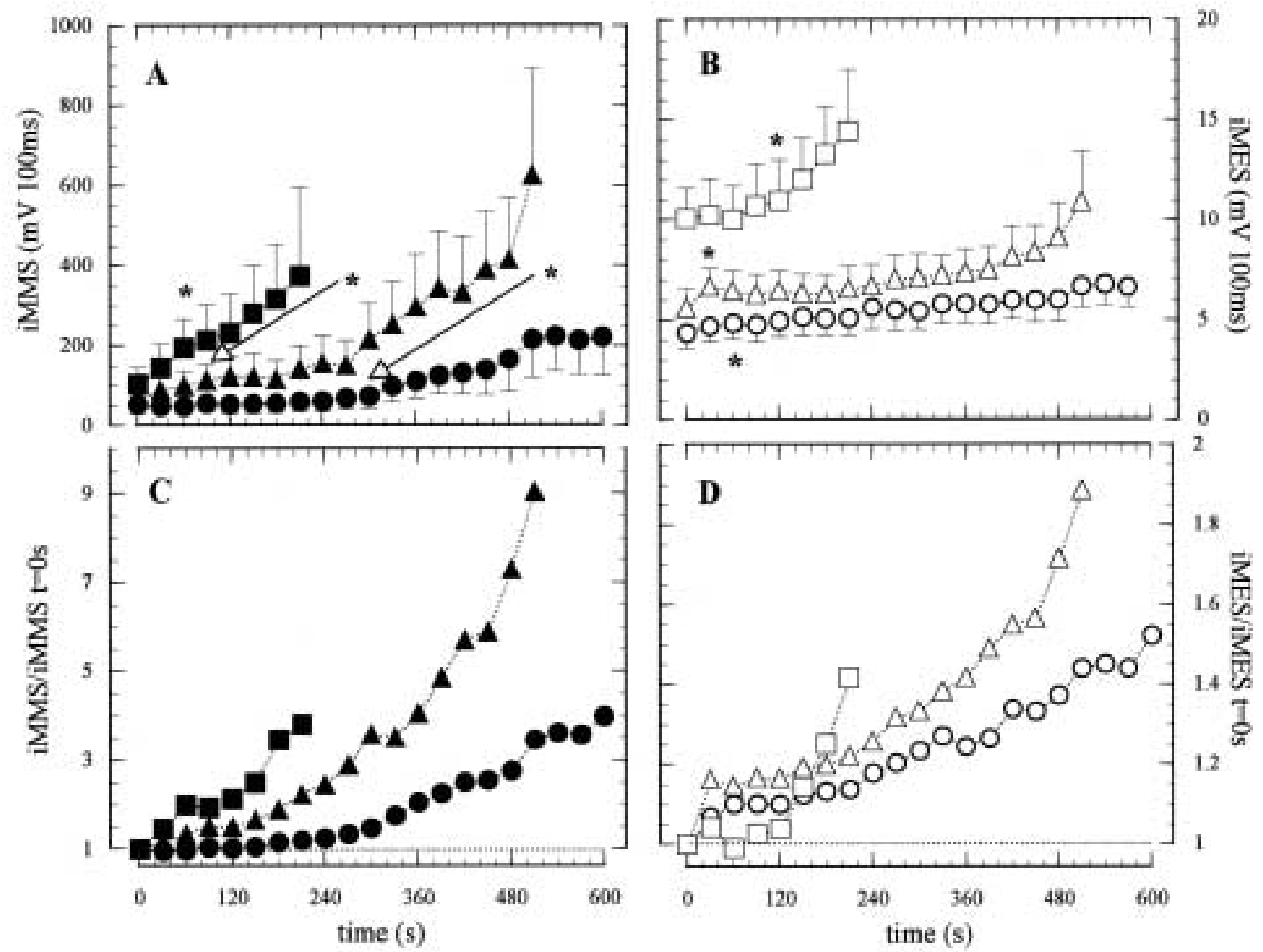

Figure 5. Changes in iMMG (A) and iMES (B) during prolonged isometric constant contraction (PICC) are shown at the target torque of $30 \mathrm{~N}$ (closed circle), $50 \mathrm{~N}$ (closed triangle) and $100 \mathrm{~N}$ (closed square) obtained from a representative subject. *means a significant difference from the value at time $=0 \mathrm{~s}$.

$\mathrm{C}$ and $\mathrm{D}$ represent the relative changes in $\mathrm{iMMG}\left(\mathrm{iMMG} / \mathrm{iMMG}_{\mathrm{t}=0 \mathrm{~s}}\right.$ ) and $\mathrm{iMES}\left(\mathrm{iMES} / \mathrm{iMES} \mathrm{t}_{\mathrm{t}=0 \mathrm{~s}}\right.$ ), respectively. Plot is the mean value from the data obtained from 7 subjects and the target torque of the recruitment threshold value of the objective MU (open and closed circles), 10\%MVC (open and closed triangles) and 20\%MVC (open and closed squares), and attached bar stands for mean value and standard deviation.

Endurance time was different among the subjects at each target torque. Latest plot at each target torque is arranged at the shortest endurance time among the subjects to make the data uniform. 
$\mathrm{V}_{\mathrm{LPD}}$ と MS- $\mathrm{V}_{\text {positive }}$ は異なった増加の推移が観察 された・ $\mathrm{V}_{\mathrm{LPD}}$ はPICC 初期に大きな増加，光の後 緩徐な増加を示した . また, 目標筋力に依存した差 異を持って推移した(A) . これに対して, MS- $V_{\text {positive }}$ は初期に緩徐な谷の後大きな増加傾向にあった . ま た，120秒まで各発揮筋力間の推移に大きな差異が 見られず，30N，50N間では360秒程度までほぼ同樣 な変化の推移であった $(\mathrm{B})$.

$\mathrm{V}_{\mathrm{LPD}}$ と $\mathrm{MS}-\mathrm{V}_{\text {positive }}$ の初期值に対する変化率を4 MUから求め光の平均值を見たところ, figure 5 と 同樣に， $\mathrm{V}_{\mathrm{LPD}}$ は MS- $\mathrm{V}_{\text {positive }}$ に比して炎の増加率 は小さかった (figures $6 \mathrm{C} \& \mathrm{D}$ ) . また, $\mathrm{V}_{\mathrm{LPD}}$ 変化 率は目標筋力間に差異が見られなかった . 更に , $\mathrm{V}_{\mathrm{LPD}}$ 変化率, MS- $\mathrm{V}_{\text {positive }}$ 変化率の時間に伴った増 加動態に差異が見られ， $V_{L P D}$ は“対数関数”的な 推移であったが, MS- $\mathrm{V}_{\text {positive }}$ は“指数関数”的な 推移を示した。

Figure $6 \mathrm{E}$ は, figures $6 \mathrm{~A} \& \mathrm{~B}$ に示したデータに ついて, 両変数間の関係を目標筋力ごとに検討した ものである、目標筋力 $30,50 \mathrm{~N}$ では有意な正の相 関関係が存在した $(\mathrm{p}<0.01)$. しかし, 目標筋力 $100 \mathrm{~N}$ では $V_{\mathrm{LPD}}$ に依存した MS- $\mathrm{V}_{\text {positive }}$ の変化動態 は見られず，100NでのPICCの全結果において両変 数間に有意な関係を見出すことは出来なかった .

$$
\text { N. 考察 }
$$

A. 運動単位間の同期的活動の指標としての LPD 振幅

運動終板での MUAP 発生から筋一腱移行部への 伝導中に筋線維部分 (運動終板と筋一腱移行部を除 いた中間部分) から単極導出される単一運動単位の MUAP は伝導に伴って, 緩徐な陽性相, 続く急峻 なスパイク状陰性相および緩徐な陽性相の 3 相性波 形を呈する.更に，第 3 相の陽性緩徐電位に一過性 の陽性電位 (LPD) が重畳する (figure 1:MUAP 参 照) .この一過性の陽性電位は筋一腱移行部からの 距離に依存して指数関数的に振幅が減少するが, 光 のピークは距離に依存せず時間的に一致した発現と なった .すなわち，電気緊張的電位の性質を有する ものであり, 弚の発現はMUAP が筋一腱移行部に 到達することによるものと考えられている ${ }^{15,16)}$. 近年，同現象は,“ muscle far field potential” (Dumitro \& King 1991) ${ }^{19)}$ "“fiber-end-effect”
(Gootzen et al. 1991) 20)“, terminal standing wave”

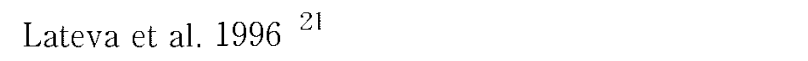
観察するMU と背景で活動する MU との電気信号 において，観察するMUAPをトリガーパルスとし て用い電気信号の加算平均値を求めると, 背景で活 動するMUAP は相殺され, 観察するMUAPのみが 抽出される.しかし, 観察対象 MUAP と時間的に 一致 (同期) して筋一腱移行部に到達する背景活動 MUAPの LPD は陽性電位として観察対象 MUAPの LPD に重畳する．すなわち，LPDは観察対象の MUAP と筋一腱移行部で同期した MUAPの数, MU の同期化活動の定性的指標となるものと考えられ $3^{(5)}$.

MU 間の同期的活動について,Stephens 等のグルー プの報告が多数なされている 22 25). Stephens 等は， 基準とした MUのMUAP と他のMUのMUAP との 放電時間差から PPSTH (pre-and post-stimulus time histograms）を構成し，2 unit間の同期確率を求め ている . 本報告での同期性は基準の MUAP に対す る不特定の MU との同期性を観察していることか ら, Stephens 等の結果との直接的な比較は困難と 考えられる .

$V_{\text {LPD }}$ は発揮筋力 (figure $3 \mathrm{~A}$ ) , iMES(B)に対し て比例関係にあった . 随意的筋力発揮時のMUの活 動樣式は, m. biceps brachiiでは88\%MVC, m. adductor pollicisおよびm. quadriceps では50\%MVC までMUの活動参加が主となり, 光れ以上の筋力発 揮には活動するMUの発火頻度の増加に依存する傾 向にある ${ }^{26 \sim 28)}$. 本実験 BICCでは筋力発揮条件を $20 \%$ MVC以下としたことから, 筋力発揮はMUの 活動参加が主となっていたことが類推される．MU の活動参加数の増大は MU 間の同期化活動の確率増 大に反映されるものと考えられる ${ }^{12)}$. Figures $3 \mathrm{~A}$ $\& B$ に示した $V_{L P D}$ の発揮筋力, iMES との比例関係 は発揮筋力増大に関与する MU の活動参加数の増大 に起因した MU 間の同期化活動の増大に因ることを 示唆するものと考える .

B. BICC 条件下における $V_{\text {LPD }}$ と MS $-V_{\text {positive }}$ の関係

$20 \%$ MVC までの目標筋力で持続的な一定筋力発 揮時に MMGおよびiMMG は時間に伴った増大傾向 にある .この増大には，1) 新しいMUの活動参加 ， 

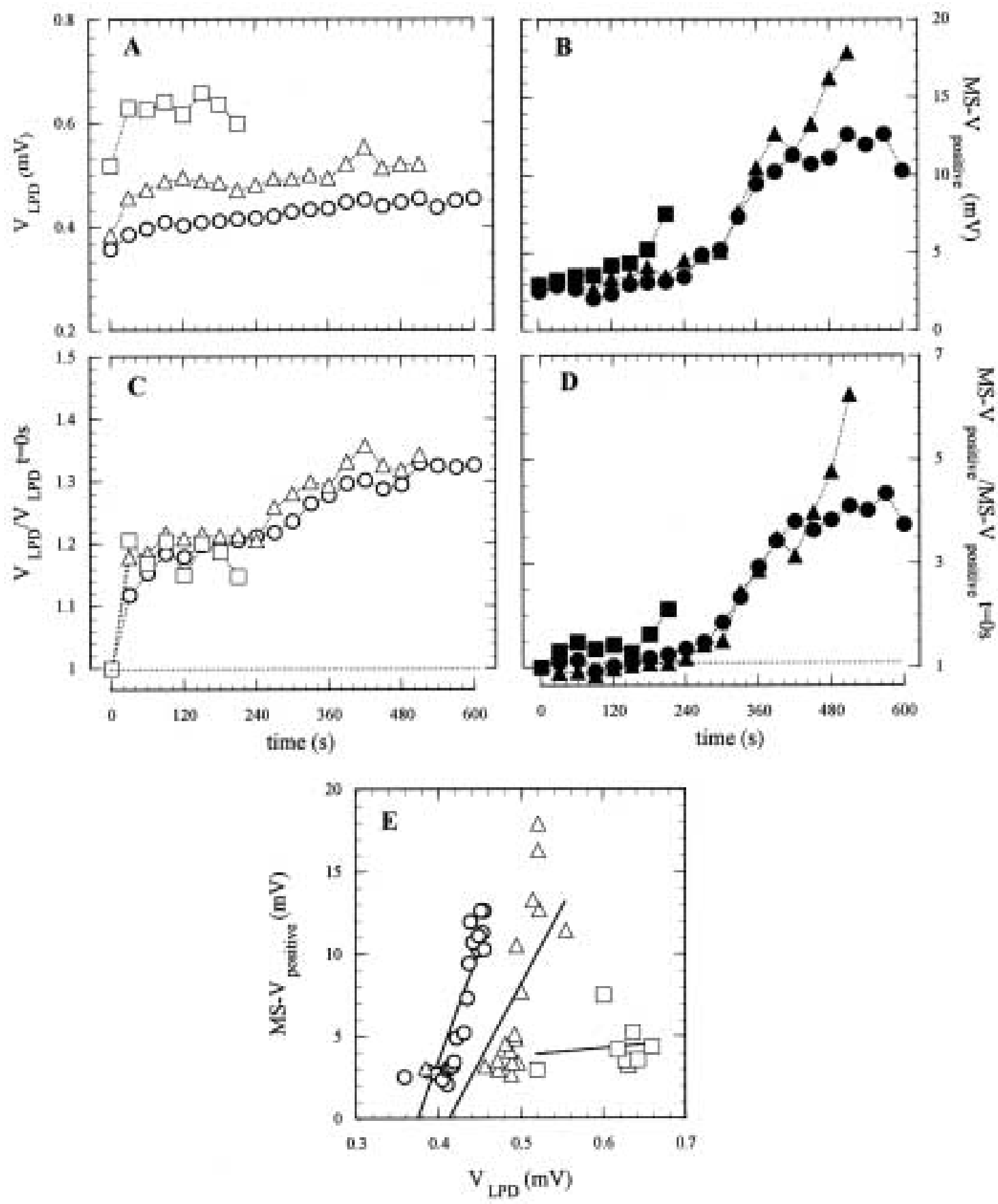

Figure 6. Changes in $\mathrm{V}_{\mathrm{LPI}}(\mathrm{A})$ and $\mathrm{MS}-\mathrm{V}_{\text {positive }}(\mathrm{B})$ during the PICC are shown at the target torque of $30 \mathrm{~N}$ (open and closed circles), $50 \mathrm{~N}$ (open and closed triangles) and $100 \mathrm{~N}$ (open and closed squares) obtained from a representative subject.

$\mathrm{C}$ and $\mathrm{D}$ represent the relative changes in $\mathrm{V}_{\mathrm{LPD}}\left(\mathrm{V}_{\mathrm{LPD}} / \mathrm{V}_{\mathrm{LPD} \mathrm{t}=0 \mathrm{~s}}\right)$ and $\mathrm{MS}-\mathrm{V}_{\text {positive }}\left(\mathrm{MS}-\mathrm{V}_{\text {positive }} / \mathrm{MS}-\mathrm{V}_{\text {positive }} \mathrm{t}=0 \mathrm{~s}\right)$, respectively. Plot is the mean value from the 4 units obtained from 3 subjects at the target torque of the recruitment threshold value of the objective MU (open and closed circles), 10\%MVC (open and closed triangles) and $20 \%$ MVC (open and closed squares).

E shows the relationship between $\mathrm{V}_{\mathrm{LPD}}$ and $\mathrm{MS}-\mathrm{V}_{\text {positive }}$ during the PICC at the target torque of the recruitment threshold value, $10 \% \mathrm{MVC}$ and $20 \% \mathrm{MVC}$. Applying linear regression analysis, the following equation was obtained.

Target torque at:

recruitment threshold value (open circle): $\mathrm{y}=136.8 \mathrm{x}-51.3, \mathrm{r}=0.8574$,

$10 \%$ MVC (closed triangle): $\mathrm{y}=93.5 \mathrm{x}-38.6, \mathrm{r}=0.6497$,

$20 \%$ MVC (closed square): $y=4.5 x+1.6, r=0.1308$.

Data was the same as the data represented in figures $6 \mathrm{~A}$ and $\mathrm{B}$. 
2) 活動するMUの発火頻度の変化，3) MU間の同 期化活動，などに起因するとされている ${ }^{2,9.10)}$. 以 上の $M M G$ 増大の 3 要因は BICC 条件下での発揮筋 カに伴った $M M G$ 増大の要因にもなりうる.

$\mathrm{MU}$ 間の同期化活動の指標として $\mathrm{V}_{\mathrm{LPD}}$ を適用し

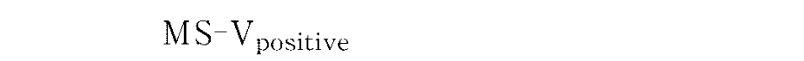
$\mathrm{BICC}$ 時の MU の同期化活動の増大は MS $-V_{\text {positive }}$ の増大方向へ反映されなかった (figure 4$)$ ). 単一 電気刺激を印加したとき, 刺激強度に依存した sound の振幅増大が報告されている ${ }^{29)}$. 刺激強度の 増大は興奮する筋線維数を増加させ , これらの筋線 維は同期して活動する.すなわち, 随意的筋力発揮 時でのMUの同期的活動 (筋収縮) はMUMS 振幅 増大に働きかけるものと推定できる．また，MUの 放電間隔変化も同時に MUMS 変化要因となる. 筋 線維 (群) への直接電気刺激時に筋線維の収縮応答 とMMG 波形を観察し, 電気刺激の頻度とMMG 振 幅, 筋力動摇間に反比例関係が存在することが報告 されている ${ }^{11)}$. MUMS 振幅の変化要因と考えられ る 2 因子は相反的な貢献性となり, BICC 条件下で, $V_{L P D}-M S-V_{\text {positive }}$ 間に意味ある関係性を見出せな かった原因は随意的発揮筋力の増大に依存した観察 するMUの発火頻度の上昇に噯蔽された可能性が考 えられる.すなわち，本実験 BICC 条件での $\mathrm{iMMG}$ 増大は新しい MU の活動参加が主要因であることが 示唆される ${ }^{7)}$.

\section{PICC 条件下における iMMGの変化動態}

持続的な一定筋力発揮時に MMG および $\mathrm{MMMG}$ は 発揮筋力に依存して種々の変化動態, $20 \% \mathrm{MVC}$ ま では増大傾向，40\%MVCでは大きな動摇, 60 と $90 \%$ MVCでは指数関数的な減少を呈することが報告さ れている ${ }^{2)}$. 本実験成績で $20 \%$ MVC以下に設定し た全ての目標筋力においても 示したが (figures 5 A \& C), iMMGの変化動態, 増 加率の推移に発揮筋力依存性が見られた。PICC初 期（2 分まで: figure 5 D) の iMES 変化率において， 変化の推移には筋力依存性が見られず, $i M M G$ とは 異なった . 機械的信号としての MMG と電気的信号 としてのMESの変化動態及び関係性を矛盾無く説 明するために，干渉波形としての MES 成立の解釈， MMG 発生機構を含めた MUMS 間干渉性など, 更に 詳細な検討が必要である。
D. PICC 条件下における $V_{\mathrm{LPD}}$ と $M S-\mathrm{V}_{\text {positive }}$ の関係性

Figure $6 \mathrm{E}$ から， V VPD と MS-Vpositive との間に は有意な相関関係があり，MUの同期的活動は MUMS の振幅を増大し，結果として MMG 信号を増 大すると解釈可能となる．しかし，Figure 6 に示し た通り， $\mathrm{V}_{\mathrm{LPD}}$ で示される MUの同期性は筋力発揮 初期に急峻, 弚の後緩除な増大傾向にあった . こ れに対して，MS- $V_{\text {positive }}$ は初期に不変又は緩やか な, 兴の後急峻な増加傾向にあった . 時間に伴った 増加傾向をとる結果は両者で共通したが，増加の推

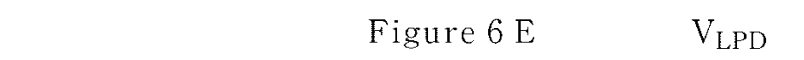
$M S-V_{\text {positive }}$ 間に有意な相関関係が得られたが，光れ ぞれの変化動態が異なることから統計上の見かけの 関係であることが考えられる．従って，MS- $V_{\text {positive }}$ は一義的に $V_{\mathrm{LPD}} に よ り$ 決定されず, 他の因子の関与 の存在が示唆された .

$5 \% \mathrm{MVC}$ 以下の目標筋力にて持続的一定筋力を 維持した時, MUの放電間隔は初期 ( 3 分程度) に 延長し，弚の後短縮する傾向がある ${ }^{30)}$. この報告 を本実験結果に適用した場合, MS- $V_{\text {positive }}$ は, 放 電間隔の延長時期で増加傾向を示すことが推定でき る.しかし, $\mathrm{V}_{\mathrm{LPD}}$ 増大の緩除な時期・ MU 放電間 隔の短縮時期で, MS- $V_{\text {positive }}$ は増大した (figures $6 \mathrm{~A}-\mathrm{D})$.

本実験条件では，MUの同期性活動の MS- $V_{\text {positive }}$ に対する影響を見出すことができなかった . 先行研 究では, LPD は筋一腱移行部に発現し, 電気緊張 的に筋部分全体に分布し, 電位の半減距離は約 $25 \mathrm{~mm}$ の値をとった（森本・加茂 1990 ; figure 2 から評価 $)^{15)}$. MUMS の振幅では, 筋線維走行方向 に対して直行方向に $5-10 \mathrm{~mm}$ の半減距離であった ${ }^{31)}$. これらの半減距離の差異から, LPDは MS $-\mathrm{V}_{\text {positive }}$ に 比較し，広範囲からの背景活動するMUのLPDによ り構成されることになる。導出範囲の違いが， $\mathrm{V}_{\mathrm{LPD}}$

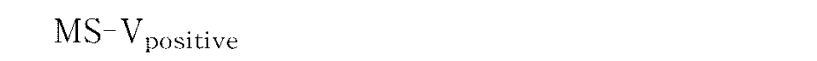
原因のひとつと考えられる．

\section{E. MS $-V_{\text {positive 増大の機序の可能性 }}$}

In vitroでの“筋音” の発現機構に関して, Barry $(1987)^{32)}$ は筋線維の興奮 (収縮) に伴った“弦樣 振動”によるとした . Morimoto \& Takemori(2007) ${ }^{31)}$ は“弦樣振動”と共に, 筋線維運動終板に早期に発現 
する興奮 (収縮) により筋線維長軸方向で“ internal shortening-internal stretching” が生じることから， 筋音波形の初期相に“筋線維の太さ変化”の成分が 内在することをヒトのMUで見出した. MMG 発生 機構に関して未だに定説が成り立っては居ないが， “筋線維側方の動き・振動” に伴い発生し, 組織中 を皮膚まで伝播した圧力波 (疎密波) を皮膚表面か ら導出していることは共通した理解と考えられる．

筋活動は筋内圧を上昇させる ${ }^{33,34)}$. Sadamoto et al. $(1983)^{33)}$ は持続的筋力発揮時で筋疲労にいたる 時点においても筋内圧が上昇することを報告してい る.筋内圧上昇は筋線維のスティフネスを増加させ ること, 観察する MU 周辺の圧力波伝播媒体のステ イフネスをも上昇させる . 媒体のスティフネス上昇 は圧力波伝播効率を上げ，圧力波を低い減衰で皮膚 表面まで伝播することが推定される . iMESが骨格 筋全体の活動性を示すと考えたとき，他の目標筋力 に比し高い初期 iMES值を示した100N で高い筋内 圧を取ることによる高いMS- $V_{\text {positive }}$ となることが 推定できる.しかし, 目標筋力間での MS- $V_{\text {positive }}$ 初期值に大きな差異は見られなかった (figure 6 B) . S $\phi$ gaard et al $(2006)^{34)}$ は水銀血圧計カフを用いて人 為的に筋内圧を加え MMG-RMS と発揮筋力との関 係を検討し，高い発揮筋力 $(40 \% \mathrm{MVC})$ では筋内圧 上昇がMMG-RMS を高值化する傾向を報告してい る.MUレベルと筋全体の MMGレベルとの観察対 象の差異，発揮筋力の差異から結論を得るには至ら ないが，筋内圧の影響に関する示唆を与える報告と 考える . 本実験での MUAP は筋表層に分布するも ので ${ }^{18)}$, 筋深層部に分布する筋線維とは異なる結 果となる可能性が示唆される .

MUMS 波形は筋温に依存した変化を示す. 低い 筋温条件で電気刺激 $(10 \mathrm{~Hz})$ を用いて誘発した外 側腓腹筋とヒラメ筋 MU の収縮特性と MMG 波形を 同時に観察し, 筋張力の低下と $M M G$ 振幅減少が平 行して発現することが報告されている ${ }^{3)} \cdot 10 \mathrm{~Hz}$ 刺 激時の MMG 振幅变化の温度依存性は, 外側腓腹筋 $1.6 \% \cdot{ }^{\circ} \mathrm{C}^{-1}$, ヒラメ筋 $1.4 \% \cdot{ }^{\circ} \mathrm{C}^{-1}$ と評価可能であっ た (Kimura et al. 2003 ; Figure 7 から評価 $)^{3)}$. 目 標筋力 $40 \mathrm{~N}$ までの持続的筋力発揮時に筋温は変動せ ず ,60Nを 8 分間持続した時点で $0.6^{\circ} \mathrm{C}\left(\right.$ 約 $\left.0.1^{\circ} \mathrm{C} / \mathrm{min}\right)$ 上昇したことが報告されている35). 本実験では筋温 を測定していない点, Kimura et al.(2003) の結果
が直線的変化でない点, 被験筋の差異などを考慮し なければならないが, 本結果での MS- $V_{\text {positive }}$ の変 化率は480秒時点で30N と $50 \mathrm{~N}$ の目標筋力で初期值 に対して約 4 (400\%) であり，MS- $V_{\text {positive }}$ の変化 を筋温変化から解釈することは困難であると考えら れた.

$$
\text { V.ま と め }
$$

持続的一定筋力発揮を $20 \% \mathrm{MVC}$ 以下の目標筋力 で行った時，iMMGは暫時増大する傾向にあった． この増大には新しいMUの活動参加, 発火頻度変化, $\mathrm{MU}$ 間の同期的活動などが関与すると考えられてい る. 本実験ではMU間の同期的活動の $i M M G へ の$ 影 響を検討するために, 単一運動単位レベルでMUAP とMUMS を同時導出し解析を行った.MU間の同期 性の指標に, 単極導出 MUAPの第 3 相の緩徐な陽 性電位に重畳するLPD を用いた，運動終板上から 導出したMUMS の初期陽性相の振幅をMMG の構成 要素として計測した。

BICC 条件下で，MS- $V_{\text {positive }}$ は $V_{\text {LPD }}$ に依存した 変化動態に無く, MU 同期性活動の MS- $V_{\text {positive 振 }}$ 幅への影響は見出せなかった .

PICC 時に $V_{\text {LPD }}$ と MS- $V_{\text {positive }}$ は共に増大傾向に あり,両変数間には有意な相関が得られた.しかし， 増大の推移は， $\mathrm{V}_{\mathrm{LPD}}$ で初期に急峻谷の後緩徐に， これに対し MS- $V_{\text {positive }}$ は初期に緩徐兴の後急峻に 増大し，増大の推移に差異が見られた .ここで見ら れた有意な相関関係が $\mathrm{V}_{\mathrm{LPD}}$ の $M S^{-} \mathrm{V}_{\text {positive }}$ への直 接的影響とは考え難い。

短時間の一定筋力発揮 $(B I C C)$ 時に $V_{L P D}$ と MS $-V_{\text {positive }}$ の関係が見出せなかった点, 持続的一定 筋力発揮 (PICC) 時での $V_{\mathrm{LPD}}$ とMS- $V_{\text {positive }}$ の関係 性を説明できなかった点を含め，本実験結果から， $\mathrm{MU}$ の同期的活動が $M S-V_{\text {positive }}$ に直接的な影響を及 ぼしたと考えるには困難であった．MUの同期的活動 のみの影響ではなく，他の因子の関与を検討する必 要が示唆された。

(受理日 平成21年 4 月 13 日) 


\section{V. 引用文 献}

1) Barry, D. T., Geiringer, S. R. \& Ball, R. D. Acoustic myography: a noninvasive monitor of motor unit fatigue. Muscle \& Nerve (1985) 8, 189-194.

2) Orizio, C., Perini, R. \& Veicsteinas, A. Changes of muscle sound during sustained contraction up to exhaustion. J. Appl. Physiol. (1989) 66, 1593-1598.

$3)$ Kimura, T., Hamada, T., Watanabe, T., Maeda, A., Oya, T. \& Moritani, T. Mechanomyographic responses in human biceps brachii and soleus during sustained isometric contraction. Eur. J. Appl. Physiol. (2004) 92, 533-539.

4) Rhatigan, B. A., Mylrea, K. C., Lonsdale, E. \& Stern, L. $Z$. Investigation of sounds produced by healthy and diseased human muscular contraction. IEEE Trans. Biomed. Eng. BMA-33, (1986) 967-970.

5) Hufschmidt, A., Schubnell, P. \& Schwaller, I. Assessment of denervation by recording of muscle sound following direct stimulation. Electromyogr. Clin. Neurophysiol. (1987) 27, 301-304.

6) Yoshitake, Y. \& Moritani, T. The muscle sound properties of different muscle fiber types during voluntary and electrically induced contractions. J. Electromyogr Kinesiol. (1999) 9, 20-217.

7) Akataki, K., Mita, K., Watanabe, M. \& Itoh, K. Mechanomyogram and force relationship during voluntary isometric ramp contractions of the biceps brachii muscle. Eur. J. Appl. Physiol. (2001) 84, 19-25.

8) Orizio, C. Muscle sound: Bases for the introduction of a mechnomyographic signal in muscle studies. Critical reviews in Biomedical engineering (1993) 21, 201-243.

9) Goldenberg, M. S., Yack, H. J., Cerny, F. J. \& Burton, H. W. Acoustic myography as indicator of force during sustained contractions of a small hand muscle. J. Appl. Physiol. (1991) 70, 87-91.

10) Madeleine, P., Jorgennsen, L.V., S $\phi$ gaard, K., ArendtNielsen, L. \& Sj申gaard, G. Development of muscle fatigue as assessed by electromyography and mechnomyography during continuous and intermittent low-force contraction: effect of the feedback mode. Eur. J. Appl. Physiol. (2002) 87, 28-37.

11) Yoshitake, Y., Shinohara, M., Ue, H. \& Moritani, T. Characteristics of surface mechanomyogram are depended on development fusion of motor units in humans. J. Appl. Physiol. (2002) 93, 1744-1752.

12) Halliday, D. M., Conway, B. A., Farmer, S. F. \& Rosenberg, J. R. Load-independent contributions from motor unit synchronization to human physiological tremor. NeuroPhysiol. (1999) 82, 664-675.

13) Stokes, M. J. \& Dalton, P. A. Acoustic myography for investigating human skeletal muscle fatigue. J. Appl. Physiol. (1991) 71, 1422-1426.

14) Dalton, P. A. \& Stokes, M. J. Frequency of acoustic myography during isometric contraction of fresh and fatigued muscle and dynamic contractions. Muscle Nerve (1993) 16, 255-261.

15) 森本 茂, 加茂美冬 単一運動単位の活動電位に観 られる電気緊張性電位成分. 体力科学 (1990) 39, 126-132.

Morimoto, S \& Kamo, M. 1990 Appearance of electrotonic component in human motor unit potentials. Jpn. J. Phys. Fitness Sports Med. (1990) $39: 126-132$. (in Japanese)

16) Morimoto, S., Gotoh, H. \& Kamo, M. Conducted and non-conducted components in spike potentials of human single motor units. J. Physiol. Soc. Japan 50, 477.

$17)$ 森本 茂·加茂美冬 単一運動単位の活動電位波形 の表面筋電位構成への貢献 体力科学 (2000) 49, $157-170$.

Morimoto, S. \& Kamo, M Contribution of single motor unit action potential to surface myo-electrical signals. Jpn. J. Phys. Fitness Sports Med. 2000, 49, 157-170. (in Japanese)

18) Morimoto, S., Umazume, Y. \& Masuda, M. Properties of spike potentials detected by a surface electrode in in. tact human muscle. Jap. J. Physiol. (1980) 30, 71-80.

19 ) Dumitru, D. \& King, J. C. Far-field potentials in muscle. Muscle Nerve (1991) 14, 981-989.

20) Gootzen, T. H. J. M., Stegeman, D. F., \& Oosterom, A. Finite limb dimensions and finite length in a model for the generation of electromyographic signals. Electroencephalog. Clin. Neurophysiol. (1991) 81, 152-162.

21) Lateva, Z. C., MacGill, K. C. \& Burgar, C. G. Anatomical and electrophysiological determinations of the human thenar compound muscle action potential. Muscle Nerve (1996) 19, 1457-1468.

22) Datta, A. K. \& Stephens, J. A. Synchronization of motor unit activity during voluntary contractions in man. J. Physiol. (1990) 422, 397-419.

23 ) Bremner, F. D., Baker, J. R. \& Stepehns, J. A. Correla tion between the discharges of motor units recorded from the same and from different finger muscles in man. J. Physiol. (1991) 432, 355-380.

24) Bremner, F. D., Baker, J. R. \& Stepehns, J. A. Variation in the degree of synchronization exhibited by motor un its lying in different finger muscles in man. J. Physiol. (1991 b) 432, 381-399.

$25)$ Datta, A. K., Farmer, S. F. \& Stephens, J. A. Central nervous pathways underlying synchronization of human motor unit firing studied during voluntary contractions. J. Physiol. (1991) 432, 401-425.

26) Basmajian, J. V. \& DeLuca, C. J. Muscles alive, $5^{\text {th }}$ ed. Williams and Wilkins, Baltimore (1985).

27) Kukuluka, C. G. \& Clamann, H. P. Comparison of the recruitment and discharge properties of motor units in human brachial biceps and adductor pollicis during isometric contractions. Brain Res. (1981) 219, 45-55.

28) Bernardi, M., Olomonow, M., Sanchez, J. H, Baratta, R. V. \& Nguyen, G. Motor unit recruitment strategy of 
knee antagonist muscles in a step-wise, increasing isometric contraction. Eur. J. Appl. Physio 1 (1995) 70, 493-501.

$29)$ Bolton, C. F., Parkers, A., Thonpson, T. R. Clark, M. R. \& Stern, C. J. Recording sound from human skeletal muscle: technical and physiological aspects. Muscle Nerve (1989) 12, 126-134.

30) Kamo, M Discharge behavior of motor units in knee extensors during the initial stage of constant-force isometric contraction at low force level. Eur. J. Appl. Physiol. (2002) 86, 375-381.

31) Morimoto, S. \& Takemori, S. Initial mechanomyographycal signals from twitching fibres of human skeletal muscle. Acta Physiol. (2007) 191, 319-327.

32) Barry, D. T. Acoustic signals from frog skeletal muscle. Biophys. J. 1987. 51, 769-773.

33) Sadamoto, T., Bonde-Peterson, F. \& Suzuki, Y. Skeletal muscle tension, flow, pressure, and EMG during sustained isometric contractions in humans. Eur. J. Appl. Physiol. (1983) 51, 395-408.

$34)$ Sфgaard, C., Orizio, C. \& Sjфgaard, G. Surface mechanomyogram amplitude is not attenuated by intramuscular pressure. Eur. J. Appl. Physiol. (2006) 96, 178-184.

35) Morimoto, S. Discharge and conduction velocity of a human single motor unit during voluntary prolonged activity. Jikeikai Med. J. (1983) 30, 111-122. 